\section{Differential salary scales}

SIR - Peter Fitzgerald (Nature 346, 388; 1993) draws attention to the differential salary scales for clinical and non-clinical academic staff in New Zealand universities. His letter touches on a number of tangential points, some of which demand clarification.

The clinical lecturer grade, in New Zealand as in most universities in the United Kingdom, is a non-tenured training grade equivalent to the hospital grade of registrar. The lowest tenured clinical academic grade is senior lecturer; appointment of clinical academics at this level provides approximate parity with the hospital grade of consultant, and does not imply a 10-year seniority differential over non-clinical staff.

Grant-funded staff of appropriate seniority in our university are designated professorial research fellows. We value their scholarship no less than we do those of similar seniority and salary on the university staff establishment, who are professors. The distinction is a distinction of funding source and of tenure, which for research fellows is necessarily limited to the tenure offered by the granting body. While it is not within my power to enforce the use of the honorific 'Professor' for professorial research fellows, I and many others within the university are consistent in our adoption and advocacy of it.

\section{Ross Boswell}

Department of Pathology,

Christchurch School of Medicine

of the University of Otago,

Christchurch, New Zealand

SIR - I am aware of two letters (John P. Gibson Nature 346, 213; 1990 and Peter H. Fitzgerald Nature 362, 388; 1993) discussing pay differentials at New Zealand universities for the same position occupied by a researcher with either medical or academic training. Both argue lucidly that if a position could reasonably be filled by a researcher of either background, then wage and status differentials are a priori both insulting and discriminatory. What surprises me is not the ill-feeling towards institutions that employ such hiring policies but that the discussion has been limited to New Zealand, when it is alive and well in the National Institutes of Health (NIH) intramural programme in the United States.

It is common knowledge within the programme that all are paid according to different schedules. These schedules and other attendant benefits can differ significantly and invariably favour the medical degree. It is also my impression that senior positions (laboratory chief and higher) are held by MD researchers in disproportionate numbers. Although this may reflect NIH's historical placement in the Public Health Service, the existing ratio of MDs to PhDs in higher positions suggests an advancement bias.

I do not oppose paying wages sufficiently high to recruit and retain researchers with medical degrees. But for positions that do not require duties reserved by law for medical personnel, and are therefore open to best qualified candidate regardless of degree type $(\mathrm{PhD}$ or MD), wages, benefits and status should be equal. Other disadvantaged groups within the $\mathrm{NIH}$ have effectively and justifiably argued that wage and advancement discrimination reflects institutional bias and not job performance. Like their salaries and opportunities, the salaries of academics should be increased to the level that makes working for NIH attractive to medical doctors.

It is important for both medical and academic doctors to have access to research opportunities. Both training programmes provide unique qualifications to those who complete them. However, there is nothing in medical training that is inherently superior to academic training for preparing one to do research. Indeed, by the nature of their training, those with academic doctorates always have at least three more years of research experience than their medical peers.

Jack A. Heinemann

NIH, NIAID, LMSF,

Rocky Mountain Laboratories,

Hamilton, Montana 59840, USA

\section{Stifling the media}

SIR - Several writers have proposed the unproven theory that AIDS developed from polio vaccines used in Africa in the 1950 s that were contaminated by simian immunodeficiency viruses from the monkey kidneys on which they were cultured. $^{1-4}$. Hilary Koprowski has threatened or launched defamation actions against some of the media outlets that have raised this theory, notably Rolling Stone and journalist Tom Curtis $^{5}$

Whatever one may think of this particular theory, the use of the courts against writers and publishers discussing scientific issues is an unwelcome development. It is likely to have an inhibiting effect on open scientific discussion ${ }^{6}$. This can be considered to be an analogue, in the scientific arena, of what have been called "strategic lawsuits against public participation" or SLAPPs, in which legal actions are used to harass citizens who speak out in a way threaten- ing to developers, government bodies and other vested interests ${ }^{7}$.

One can imagine the effect on science if it had been considered appropriate to take legal action against Darwin for his writings on the origin of species, against writers commenting on nuclear weapons policy-making, against publishers dealing with the issues surrounding genetic engineering and so on. In such cases, it is almost inevitable that someone's views will be explicitly or implicitly brought into "disrepute". Fortunately, it is generally recognized that scientists sometimes make mistakes, are wrong, or undertake research or applications with inadvertent adverse consequences. Without learning from mistakes, they are bound to be repeated. It would be unfortunate if discussion of possible inadvertent consequences of scientific activity could be inhibited by legal action.

\section{Brian Martin}

Department of Science and Technology Studies,

University of Wollongong,

New South Wales 2522, Australia

1. Lecatsas, G. \& Alexander, J. J. S. Af. med. J. 76, 451 (1989)

2. Pascal, L. Science and Technology Analysis Research Programme Working Paper 9 (University of Wollongong, NSW 2522, Australia, 1991)

3. Curtis, T. Rolling Stone 626, 54-61, 106-108 (19 March 1992).

4. Elswood, B. \& Stricker, R. B. Research in Virology (1993, in press).

5. Science 259, 180 (1993)

6. Martin, B. Philosophy and Social Action 12, 5-23 (JanMarch 1986).

7. Canan, P. \& Pring. G. W. Social Problems 35, 506-519 (1988).

\section{Beating fraud}

SIR - Much has been written about scientific misconduct allegations and the need for science to police itself better. However, it seems to me that scientists and journalists need a fundamental change of attitude towards misconduct to address this issue properly. To start with, we should refrain from the use of the inappropriate term 'whistleblower' to refer to the person who exposes potential misconduct. This unfortunate usage symbolizes the negative effect that bringing misconduct to light can cause, and careers are often irreparably damaged as a consequence. In other words, only when society does not devalue the person with enough courage to expose potential cases of misconduct will science really be able to police itself adequately and convince others that it can, which is of particular importance in today's world of accountability and limited research budgets.

Robert D. Nicholls

University of Florida Brain Institute,

Box 100244

JHM Health Science Center,

Gainesville, Florida 32610-0244, USA 